\title{
Additively Manufactured Aluminium AlSi10Mg Alloy
}

\author{
Michaela Fousova ${ }^{1,2}$, Drahomir Dvorsky ${ }^{1,2}$, Dalibor Vojtech ${ }^{1}$ \\ ${ }^{1}$ Department of Metals and Corrosion Engineering, Faculty of Chemical Technology, University of Chemistry and tech- \\ nology Prague, Technicka 5, 16628 Prague 6, Czech Republic. E-mail: fousovam@vscht.cz, dvorskyd@vscht.cz, voj- \\ techd@vscht.cz \\ ${ }^{2}$ Institute of Physics, Academy of Sciences of the Czech Republic (AS CR), Na Slovance 1999/2, 18221 Prague 8, Czech \\ Republic.
}

\begin{abstract}
Additive manufacture (AM) is a promising tool to produce sophisticated parts, for example for automotive and aircraft applications, as it excels in astonishing geometry freedom. For such applications, aluminium alloys are of a particular interest thanks to their excellent strength-to-weight ratio. In comparison with the conventional casting of aluminium-based materials, AM brings about some characteristic features; especially unique microstructure evolution. For the real use of additively manufactured parts it is thus important to compare material properties obtained by AM with the cast state. Therefore, this paper brings a comparison of AISi10Mg alloy produced additively by selective laser melting (SLM) technology with conventionally cast alloy. It is focused on microstructure characterization and mechanical properties assessment. Results of this comparison show that SLM yields very fine microstructure, what reflects in significantly higher mechanical performance over cast material.
\end{abstract}

Keywords: Aluminium alloy, AlSi10Mg, Additive manufacture, SLM

\section{Acknowledgement}

The authors wish to thank the Czech Science Foundation (project no. P108/12/G043) for the financial support of this research and to the NETME Centre for the specimen manufacture.

\section{References}

[1] YE, H. (2003). An overview of the development of Al-Si-Alloy based material for engine applications. In: Journal of Material Engineering and Performance, Vol. 12, No. 3, pp. 288-297.

[2] OLAKANMI, E. O. (2013). Selective laser sintering/melting (SLS/SLM) of pure Al, Al-Mg, and Al-Si powders: Effect of processing conditions and powder properties. In: Journal of Materials Processing Technology, Vol. 213, No. 8, pp. 1387-1405.

[3] BREMEN, S., MEINERS, W., DIATLOV, A. (2012). Selective Laser Melting. In: Laser Technik Journal, Vol. 9 , No. 2, pp. 33-38.

[4] LOUVIS, E., FOX, P., SUTCLIFFE, C. J. (2011). Selective laser melting of aluminium components. In: Journal of Materials Processing Technology, Vol. 211, No. 2, pp. 275-284.

[5] FOUSOVÁ, M., VOJTĚCH, D., KUBÁSEK, J., DVORSKÝ, D., MACHOVÁ, M. (2015). 3D Printing as an Alternative to Casting, Forging and Machining Technologies? In: Manufacturing Technology, Vol. 15, No. 5, pp. 809-814.

[6] BRANDL, E., HECKENBERGER, U., HOLZINGER, V., BUCHBINDER, D. (2012). Additive manufactured AlSi10Mg samples using Selective Laser Melting (SLM): Microstructure, high cycle fatigue, and fracture behavior. In: Materials \& Design, Vol. 34, pp. 159-169.

[7] READ, N., WANG, W., ESSA, K., ATTALLAH, M. M. (2015). Selective laser melting of AlSi10Mg alloy: Process optimisation and mechanical properties development. In: Materials and Design, Vol. 65, pp. 417-424.

[8] WEI, P., WEI, Z., CHEN, Z., DU, J., HE, Y., LI, J., ZHOU, Y. (2017). The AlSi10Mg samples produced by selective laser melting: single track, densification, microstructure and mechanical behavior. In: Applied Surface Science, Vol. 408, pp. 38-50.

[9] BUCHBINDER, D., SCHLEIFENBAUM, H., HEIDRICH, S., MEINERS, W., BÜLTMANN, J. (2011). High Power Selective Laser Melting (HP SLM) of Aluminum Parts. In: Physics Procedia, Vol. 12, pp. 271-278.

[10] LI, W., LI, S., LIU, J., ZHANG, A., ZHOU, Y., WEI, Q., YAN, C., SHI, Y. (2016). Effect of heat treatment on AlSi10Mg alloy fabricated by selective laser melting: Microstructure evolution, mechanical properties and fracture mechanism. In: Materials Science and Engineering: A, Vol. 663, pp. 116-125.

[11] NOVA, I., MACHUTA, J. (2016). Microstructure of aluminium alloys casting intended for cyclical thermal stress. In: Manufacturing Technology, Vol. 16, No. 5, pp. 1085-1091. 
[12] SLM-SOLUTIONS-SLM-280HL, 2014. 3Dlaboratory. http://3dlaboratory.cz/rapid-prototyping/slm-solutionsslm-280hl/ (accessed May 03, 2017).

[13] GONG, H., RAFI, K., GU, H., STARR, T., STUCKER, B. (2014). Analysis of defect generation in Ti-6Al-4V parts made using powder bed fusion additive manufacturing processes. In: Additive Manufacturing, Vol. 1-4, pp. $87-98$.

[14] WU, J., WANG, X. Q., WANG, W., ATTALLAH, M. M., LORETTO, M. H. (2016). Microstructure and strength of selectively laser melted AlSi10Mg. In: Acta Materialia, Vol. 117, pp. 311-320.

[15] THIJS, L., KEMPEN, K., KRUTH, J.-P., VAN HUMBEECK, J. (2013). Fine-structured aluminium products with controllable texture by selective laser melting of pre-alloyed AlSi10Mg powder. In: Acta Materialia, Vol. 61, No. 5, pp. 1809-1819.

[16] ION, J., (2005). Laser Processing of Engineering Materials: Principles, Procedure and Industrial Application, Butterworth-Heinemann.

[17] MASKery, I., ABOUlKhair, N. T., CORFIEld, M. R., TUCK, C., ClARE, A. T., LEACH, R. K., WILDMAN, R. D., ASHCROFT, I. A., HAGUE, R. J. M. (2016). Quantification and characterisation of porosity in selectively laser melted Al-Si10-Mg using X-ray computed tomography. In: Materials Characterization, Vol. 111, pp. 193-204.

[18] SPIERINGS, A., SCHNEIDER, M., EGGENBERGER, R. (2011). Comparison of density measurement techniques for additive manufactured metallic parts. In: Rapid Prototyping Journal, Vol. 17, No. 5, pp. 380-386.

[19] TRADOWSKY, U., WHITE, J., WARD, R. M., READ, N., REIMERS, W., ATTALLAH, M. M. (2016). Selective laser melting of AlSi10Mg: Influence of post-processing on the microstructural and tensile properties development. In: Materials \& Design, Vol. 105, pp. 212-222. 